\title{
MANAGING INSTRUMENTS OF THE FUTURE
}

\author{
INSTRUMENTY ZARZĄDZANIA PRZYSZZOŚCIĄ
}

\author{
Nataliya Yudina, PhD \\ National Technical University of Ukraine "Igor Sikorsky Kyiv Polytechnic Institute", Industrial Marketing Department \\ 1/37 Yangel st., b.8, of. 81, Kyiv, Ukraine \\ Nataly.Yudina@meta.ua_ORCID 0000-0002-1730-9341 \\ DOl: 10.2478/minib-2020-0027
}

\section{ABSTRACT}

The studies demonstrated that the sustainable development concept hadn't hinged the justification on hopes because the previous crisis of the global economy was synchronous in almost all countries in the world. The innovative approach to management of the future and to forming a new concept of the humankind development is very important today. The hypothesis that in the future the culture instrument for management of human activity will have to turn into a third component for a new correction of the humankind ideology in the association of the market and the hierarchy is proposed. The meaning of the humankind history learning is highlighted. But it is also demonstrated the difficulties for the people to learn the Big Data of historical information in details. The new approach to the process of history learning at higher educational establishments is proposed, namely: to learn historical information by the reverse chronological order from the contemporary history step to the old ancient history, from the special to the general: from learning history of the native country to learning history of all countries over the world. It places emphasis that under the conditions of the information chaos anyone might become the author (or several authors) of the global culture of the future as the main threat for the humankind.

Key words: culture, humankind values, ideology, futurology, management of the future, management concept, instruments of management 


\section{ABSTRAKT}

Badania wykazały, że koncepcja zrównoważonego rozwoju nie opierała się na uzasadnionych nadziejach, ponieważ poprzedni kryzys światowej gospodarki wystąpił równocześnie w prawie wszystkich krajach świata. Innowacyjne podejście do zarządzania przyszłością i ksztaltowania nowej koncepcji rozwoju ludzkości jest dziś bardzo ważne. Stawia się hipotezę, że w przyszłości kulturowy instrument zarządzania działalnością człowieka będzie musiał stać się trzecim składnikiem nowej korekty ideologii ludzkości — w powiązaniu z rynkiem i hierarchią. Podkreśla się znaczenie uczenia się historii ludzkości. Wskazuje się jednak również trudności, z jakimi borykają się ludzie w szczegółowym poznawaniu Big Data informacji historycznych. Proponuje się nowe podejście do procesu uczenia się historii w szkołach wyższych, a mianowicie: uczenie się informacji historycznych w odwrotnym porządku chronologicznym od historii współczesnej do starej historii starożytnej, od historii specjalnej do ogólnej, od uczenia się historii kraju ojczystego do uczenia się historii wszystkich krajów na świecie. Podkreśla się w nim, że w warunkach chaosu informacyjnego każdy może stać się autorem (lub kilkoma autorami) globalnej kultury przyszłości jako głównego zagrożenia dla ludzkości.

Słowa kluczowe: kultura, wartości ludzkie, ideologia, futurologia, zarządzanie przyszłością, koncepcja zarządzania, instrumenty zarządzania

JEL: $M 30$

\section{Introduction}

The concept of Globalization, the concept of Sustainable Development and the next concept of 17 Sustainable Development Goals could not justify themselves (Veber, 2013; Yudina, 2020). The global economy crisis was synchronous for most countries in the world in 2008, in 2012 and in 2020 too. Its catastrophic consequences for the whole group of countries already demonstrated the failure of the earlier approaches to effective management of the humankind development after 2008 and 2012. The word "chaos" repeatedly sounded in the speeches of the leaders of majority countries of the world at the United Nations General Assembly in 2012. And the same chaotic situation we can watch in 2020 because most countries in the world 
are moving now into the next synchronic worldwide economic crisis because of the pandemic of COVID-19. A leader without a strategy is one of the most impact and likelihood risk for the world in 2020. This situation needs an innovative approach to management of the future and forming a new concept of the humankind development.

\section{Ways for the transformation of the concept of the management of the future}

There are three traditional instruments of management of the human activity: the hierarchy, the culture and the market (Ivenko, 1992, pp. 14-15). The transition from the concept of globalization to the concept of the sustainable development was the process of the humankind ideology that was updating by the association of two traditional instruments for managing of the human activity, namely: the hierarchy and the market. It is logical to expect that the culture will have to become the third component for a new correction of the humankind ideology in the future. This instrument of the management of the human activity will have to become more powerful than the market or than the hierarchy have been. The culture will have to solve more difficult tasks on the global level that other two instruments of the management of the human activity (the hierarchy and the market) haven't solve in past.

The culture, as the instrument of the management of the human activity, is the upbringing of some behavioral norms in the society, its evaluation criteria. The breach of such general accepted norms by somebody means punishments for offender in the society with high culture. The punishments involve external condemnations by the people or the internal self-condemnations (morality or conscience). Such condemnations are the basis for management of any human activity.

According to the traditional definition, the culture means a complex that includes the humankind achievements in the production, social and intellectual directions, the high level of something, the high development of something or the high skills (Ozhogov, 1988, p. 252). From the perspective of this definition the culture defines values of achievements for the people since these values are important for the society. The culture makes the 
targeted exposure to the people by its system of the values that motivate the people to achieve dominant positions in these valued spheres. For example, C.N. Parkinson separates the two kinds of the people status in the society depending on its system of the values (Parkinson, 1989). In some cases the high status profile based on an individual authority in the society and its symbol is a badge of the honour (for instance, the Distinguished Service Order). In others the high status profile bases on money and monetary wealth and its symbol is an expensive automobile brand. In the countries with aristocratic traditions (C.N. Parkinson provides Britain as an example of these countries) such factors as an occupational status (rank), a social class background, education, mesomorphy and stout heartedness are important for the people to achieve the higher profile. In deprived such traditions countries (C. Northcote Parkinson provides the United States of America as an example of these countries) it's enough for a member of the society to have high money and profits only. The value of the specific achievements becomes a driving force and motivation of the behavior of each member of the society. So, the specific culture (that is public) manages the people, their specific behavior and specific achievements by forming the specific public values.

For instance, at the enterprise level the culture has been already used as the instrument of high management by the leaders of companies for a long time. However, under the conditions of the economic crisis, the marketing role becomes much more influential and mighty not only at the big enterprises level but at the particular cities level, too (Fomichov, Banin, Skachkov, Lysak, Gaievskiy, and Yudina, 2019). That is why the culture that is used as the effective instruments of management at the enterprise level will be able to be used upon the analogy at the humankind level at large. So, we will initially center attention on approaches to the culture at the enterprise level to adopt them to management of the future at the humankind level.

The two approaches to the culture can be distinguished and be used as the instrument of management of the enterprises future (as for management of their employees, so for management of consumers' behavior): the traditional approach and the futurological approach (Smovzh, 2013). The traditional approach to the culture supposes the particular enterprise to achieve particular financial goals by studying of the 
predefined consumption requirements of the target audience (the approach "from-today-to-tomorrow") and forming the culture of using the products that satisfy these requirements. However, this approach can also create a negative effect for all of the humankind because some consumers' demand can be harmful.

The futurological approach is predicated on turning all of the management system to the opposite side "from-the future-to-today" (Dorofeev and Beliakova, 2012). It means managers have to study of not only already predefined consumption requirements, but also future potentially-enable global problems and requirements of the humankind. Following on from the results of the futurological studying, the task has to be set to form new consumption requirements that will be "meaningful" for all of the humankind. The culture can form a particular knowledge system of its target audience like education or pedagogy can. That is why the futurological approach to the culture supposes an advanced function of the culture to be ahead of time. The culture as the instrument of management of the future should divine what the future and the trends of the life will be like to develop a strategy of the company and its target audiences (Dudina, 2011, p. 55).

There are many publications dedicated to developing long-term (futurological) management. For instance, there are works of such authors as G. Grant, P. Kotler, V.D. Dorofeev, V.A. Belyakov, E.E. Mazur, R.V. Tkachenko and many others. On this evidence there are works of D.S. Martianov, N.M. Imaeva, T.S. Tuzovskiy and others. But the authors have centered attention on the futurological approach to the culture as the particular enterprise instrument of management of the enterprise future not so far. On the one hand it can be attributable to futurology to which there is no the one-for-all single approach but on the other hand futurology means developing the long term strategy of some big companies such as Google, British Telecom, IBM, Cisco and others. However, it is not a widely mass popular approach at other enterprises yet but it is one of innovate business trends that will be expanding in markets in the future soon.

The culture as the instrument of management of the future makes the targeted exposure to the people behavior. Taken in that light the culture means "a process of creating a system of points of view and ideas that the people realize and appreciate the reality and the each others, social 
problems and conflicts; it also forms goals (programs) of social activities that leads to change (to develop) that social relationships and attitude of minds" (Yudina, 2014). As for the culture targeted exposure that reflects interests of the particular limited social group (or the social class, the leader of the company, the collective of employees, etc.) in order to managing of the other people (the consumers, employees, etc.) the culture can carry a negative connotation. In accordance with some authors (Imaeva, 2010) such way of the culture implementation comes down to a nonobjective retranslation of the reality that is important for the only particular group. For instance, running the culture of smartphones selfie shooting by the famous brand of mobile gadgets (Nechitailo and Yudina, 2015) or creating the "Pokemon Go" mobile games culture (Syuniakova, 2016; Kuzmich, 2016) are bright demonstrations from the one hand of the effective implementation of the culture for commercial purposes but from the other hand they demonstrates powerful negative consequences for the whole Humankind because the culture can create pseudo-values.

Conversely, the other authors such as V.V. Zheltov, A.A. Zinoviev, Y.I. Prohorenko and etc. separate positive points of the implementation of the culture as the instrument of management, for example, of developing of the future of the society. V.R. Feldeman concentrates on the culture function that supposes the society to be a self-organizing system. T.S. Tuzovskiy notes the culture ability to form the visualization of the future in the society. Such approaches to the culture as the instrument of the management of the future reconciles with the "from-inside-to-outside" approach to planning: from inside of the social group of the authors of the culture out to the other social groups of potential consumers, employees, the society to integrate them around the culture.

However, from our point of view the effect of the implementation of the culture (positive or negative) isn't the culture in and of itself. We propose the culture means being a part of the communication source to manage its target social group. The effect of implementation of the culture depends on its content, ideology, belief system that turn into the appraisal criteria system of the social group. The appraisal criteria system can correct the target audience view of the world thanks to its ability to simplify a decisionmaking process. So, the behavior of the target social audience becomes preprogrammed by the culture that has been taken for granted. That is 
why this group of the people is controlled by the culture. In accordance with the advanced elaboration likelihood model (Petty, Rucker, Bizer, and Cacioppo, 2004) under the determined situation conditions mind elaborates information by not the logical path but by the shorten emotional path with psychological sets and associations. For example, the action process of this communication function of the culture is similar to a desktop shortcut that shorts a route to a file (Cialdini, 2006, pp. 16-33).

Under the conditions of the information society when the information is increasing by the exponential law in the blow-up regimes (Kniazeva and Kurdumova, 2002) the demand for a culture will be increasing very much because of any culture can simplify a large amount of the information in the information chaos. For example, a marketing activity developing brand awareness, a loyalty and a culture of consumption simplifies a decisionmaking process of buying the product among many other similar products. The high customer loyalty to the brand saves customers their time for all their future buying a product in the product category. Taking into account that the marketing tools can have an impact on the consumers' behavior by forming needs and creating a demand on a product the marketing activity is based on different kinds of the cultures and it can form new cultures in the society.

According to the futurological approach to the culture as the instrument of management of the future that determines the culture order as "fromoutside-to-inside" order the culture has to characterize not only a social group that has been created by this culture but also reflect the society interests in the future. By then, in contrast to the traditional approach the cultural influence changes its order: particularly just human interests not the interests of the social group that creates the culture have to determine the cultural idea content and the system of points of view of that social group. The subjects (persons that are the culture bearers) have to become units of the culture management and that is the key element of the futurological approach. It can be explained by the culture function of managing and running the behavior of the subjects of the culture to accord it with desired future state that is preferable for the humankind.

The subjects of the culture could be separated to the two groups: one of them is group-internal and another is external. For example, the board of the company and its employees are group-internal subject of the culture. 
That is why it's important the creators of the culture to have to realize all of futurological consequences and their responsibility for their management decisions. All of futurological goals of the culture that have been formulated in accordance with the futurological approach can lead to receiving less profits than one's due and insufficient receipt of economic effect that is possible by the traditional approach. That is why for persons that make management decisions in regard to the culture their internal criterions of the culture have to be much more power than their economical criterions are. So, the culture by the futurological approach has to develop the specific limitations for the internal subjects of the culture. The moral and the humankind values have to become these limitations as the initial and original limitations that have been given to the humankind by the nature. Moral and the humankind values form rules of high top priority that define behavior, spiritual values, moral virtues that a person needs to have in the society and has to abide by these rules.

The problem of moral and the humankind values is becoming ever more relevant now in the "post-social society" in accordance with I.V. Efimchuk's approach (Efimchuk, 2005). It can be explained by the traditional limitations in the form of legislations and public norms that are loosing their might because of growing corruption and existing ability some corruptionists to avoid shouldering the responsibility. Indefinitiveness of the information post-social society needs to find new additional criterions of making management decisions that the culture as the instrument of management can become and have to become in the future. For example, on the enterprises level such instrument ordered to the internal subjects of the culture can include the Oath of employees (like the Oath of Hippocrates) that must be given public by a flourish of trumpets.

The target audience of customers are the external subject group for managing by the culture. The critical particularity of the culture for its external target group is the pre-requisite of the culture correspondence to the already pre-existing assessment criterions of the target audience. That is why it's more effective not to search the people's behavior differences but find the similarity of their needs. But the marketing instruments of the segmentation have led to a lot of differences of the people (Gelovani, Britkov, and Dubovskiy, 2010). Its consequences are many different 
definitions of the human values, what is right and what is wrong that could be a starting point to form the shared culture.

At the humankind level absence of the universal approach to understanding moral and the universal humankind values is the hot problem of the culture in the information and post-social society. However, in accordance with the analogy of an innovation that is entering in the market, if marketing tools are used, the culture will have its followers very soon. When a number of such followers reaches a critical mass, the process of the spreading the culture that is proceeding by the exponential law will get into the blow-up regime, too. It means that the problem of the resurrection of the culture and the universal humankind values will be resolved in the long-term perspective. Under the conditions of the transition to the controlled market relations that at the global level are the association of such instruments of the management of the people, as the market and the hierarchy the role of the factor of human error is coming on the front burner. Taking it into consideration, the developing of the recommendation to solve the particular tasks list of the management of the human resource by the culture is critical important at the companies level.

The problem of forming of the culture at the companies level (the corporate culture or the organizational culture) has been developing in papers by E.B. Bannikova, T.Y. Bazarov, E.D. Vilhovichenko, A.P. Yerorshin, B.L. Yeremin, G.P. Schedrovitskij and the others. By then, there is not universal understanding of the meaning of the terms the "corporate culture" or the "organizational culture".

In accordance with the functionalistic concept (Vetoshkina, 2009) the culture is based on the functional unity of the society as the system of the relationships between the social and cultural structures (Schedrovitskiy, 1995, pp. 228-232). As Y.B. Bannikova sais, there is a lot of the companies leaders' requests to forming organizational culture because of existing opinion of its efficiency as the instrument of the management of the employees (Bannikova, 2012). So, Bannikova proposes to determine the culture as "the sustainable self-reproducing system that is a form of the organization of the interrelationship of a man and the society, those parts that are be perceived as a long-term existing phenomena of the social reality" (Bannikova, 2012, 57). 
According to T.A. Vetoshkina's point of view, complementary to the functionalistic concept the genetic aspect is very important for understanding the culture (Vetoshkina, 2009). Taken in that light, existing and supposed examples of the cultures are lined together. So, she proposes to determine the culture as the opportunity to manage the human resources (or human capital) of the company. But there are not many scientific works about using the culture in the companies running. In the most works (Vihanskiy and Naumov, 2000; Bazarov and Yeremin, 2002; Kibanov, 2002) the culture is considered without going into details on the broad outlines. Some authors equate the "corporate culture" and the "organizational culture", others draw a line between them. But all of them emphasize that the culture is one of the effective instruments of the management of the company. From our point of view the most appropriate definition of the culture as the instrument of the management of the company that can be used in a more comprehensive sense in this article is the definition by T.Y. Bazarov at al. (2002, p. 405). He sais the culture is a difficult complex of presuppositions that are accepted by all members of the particular organization without any proof. These rules establish the standard of the employees' behavior. The culture at the companies' level makes itself felt in philosophy and ideology of corporative governance, values, expectations, behavior. The culture makes it possible to form and predict the employees' behaviors and reactions in the critical situations in the future (Bannikova, 2012).

E. Schein defines the culture as a complex of the basic suppositions, devices that have been found out or developed by the group of leaders to solve problems of adopting the company to external environment of the organization and internal integration of the employees (Schein, 1985, p. 12). There are also some others definitions of the culture as the instrument of the management at the companies' level but they don't allocate a source of its genesis. Taken at that light, the corporative culture has to be formulated by first persons of the company, it integrates special values of the organization, its traditions, and standard of the behavior (Bannikova, 2012). Conversely, the organization culture is an non-formal system that has been formed self-existing and spontaneous by employees of the company in the course of their works. 
Most of the authors agree that the culture is a difficult complex of important presuppositions that don't need to be confirmed and are accepted by most of the collective of the people. Investigations in the culture fields of science have their roots in the remote past. For example, H. Trace thinks that the first attempt to study the culture as the instrument of management was in 1930th by the think-tank with their leader E. Majo (Vilhovichenko, 1994, p. 12). The scientists conducted the experiment to study the different factors influence to the labor efficiency or the particular company. The results showed that classical management hadn't taken into account such very important but latent factors as physiological and sociological factors (for example, conviction, moral climate, principles and so on). So, feelings of the individual on the basis of the belonging to the group of other people with the general values run the consideration of the culture from the management point of view. Then in 1980th-90th many scientists were interested in studying the culture at the companies' level as the instrument of management of the economical efficiency of the company running (Bannikova, 2012).

Now it's important and possible on the analogy with the companies' level to use this approach to the culture but at the other level - at the humankind level for managing of its future. So, the traditional definition of the culture suggests the need to establish not only the processes of the carefully keeping and the accumulation of the historical heritage of the humankind, the humankind achievements, but also the processes of indepth study of the history by people in all countries. It transforms the role of the education. But it should be taken into account that it will be very difficult for the people in the future to learn all of the humankind history in detail in the global scale of the Universe. The amount of past historical information is growing rapidly. Therefore the modern human begins to limit the scope of information by learning contemporary history only. But such approach can lead the humankind to repeating the mistakes of the past. The trendy all-life-learning concept directs the people to lean only technologies and new knowledge which will just appear in the future. But it is also very important to direct the people to learn the world history of the humankind. It is proposed a new approach to increase the efficiency of this process at higher educational establishments (for example, during learning history of economics and economy thought), namely to learn the historical information: 
- in the reverse chronological order from the new contemporary modern history to the old ancient history,

- from the special to the general: from learning the history of the native country to the history of all countries over the world.

This approach differs from the traditional approach to learning the history. So, the traditional approach proposes to learn the historical events in the straight chronological order: from the general points to the particular ones. For example, in Ukraine the schoolchildren learn the world history at first. And only in the high school they learn the history of Ukraine. But the resent researches identified the interesting reasons by which after the graduation the "C"-students are more successful than "A"-students are (Hardy, 2016). Early during the industrial age the industrial enterprises needed the compliant and obedient workers that had to be ready to follow rules. This was reflected in the evaluation of the educational system. The A-students were evaluated by high marks ("A") because they had followed all rules of the tutorials excellent. Such approach to the education created the standardized people behavior for different standardized situations. The "C"-students got bad marks because they hadn't follow rules. That is why the "C"-students become the creators and not the doer. By their outside fixed attitude to the common rules they formed the creative mind and reached more success results in their life.

The traditional approaches to education are criticized under the conditions of the humankind transition from the industrial society to the information society. That is why they have to be updated. Many sciences are going through the revolutionary changes, so, there is the beginning of the new era of the scientific breakthroughs. For example, the phenomenon of the quantum entanglement (two quantums can influence to each other through long distances) couldn't be explained by the traditional approaches for a long time (Hel, 2015). In particular according to the traditional principle of the locality, the particles can influence to each other if they are located next to each other in the space. But the innovative explanation of the phenomenon of the quantum entanglement has destroyed the spacetime concept. It proposed to explain this phenomenon from the position of the world space but not from the locality. By the one of modern hypothesis of the quantum physics, the interconnected events are just the reflections 
of the projections of the only one event like only one particle of the color glass is reflected in mirrors of the kaleidoscope. This process creates the illusion of the synchronous motion of many identical particles. This new approach provoked the intense scientific debates and showed the necessity of the reinterpretation of the traditional physics approaches.

The distraction of the fundamental principles, on which the old knowledge based, promotes the creation of new knowledge. It allows to explain a lot of events, which couldn't be explained by traditional approaches. But these transformations have to change the educational system at all. In particular they have to change the approaches to the process of the learning of the history. But it must be very careful to reform this system because there are some hidden threats.

Firstly, there is no guarantee that the people will have plenty of the life time in the future to learn the whole history of the whole World and than to apply this knowledge in their practices. Secondly, the growth of the amount of information leads people to the procrastination (Gustavson, 2015), to the degradation and to the "Future Shock" (the fear of the future) (Toffler, 2002), although the resent neurophysiologists' researches showed that the information volume which can fit into the brain is near by the petabytes, so, the Big Data of the internet can fit into the brain (Bartol, Bromer, Kinney, Chirillo, Bourne, Harris and Sejnowski, 2015).

The modern people minds need the simplification of information with simple postulates, restrictions, common to all humankind laws and values. The humankind has gone to the line when it's necessary the culture to be in its classical and ideological meaning (Yudina, 2017). Further in the article such culture will be called as the global culture of the future.

Ones the participants of one of my trainings discussed the expediency and the consequences of the Artificial Intelligence (AI) creation as the management tool of the Big Data. Somebody considered that AI would bring the negative consequences and destroy the humankind. But somebody thought that AI would be very good because it (like "Highest Mind") would know everything instead of the peoples. And the peoples would only have to trust such technological management. The one of the participants noted that the people would not have to waste time for learning the evidence. From her point of view it would be enough to learn almost ready conclusions as fundamental truth. On the one hand this point 
of view confirms the previous conclusion about the demand on the culture in its ideological meaning (the postulates without learning the prehistory). It's important to note that this demand is ceasing to be hidden and the target audience also realizes this.

But on the other hand this point of view explains the popularity of the social networks which use the modern format of short messages ("twitters" and "videotwitters") among the people (Nechitailo and Yudina, 2015). The social networks will contribute to scale the global culture of the future. The humankind is in the information chaos now. In the endless information stream a person begins to lose any reference points and the criteria of what is right and what is not right because there are not the generally accepted rules and values. In the social networks the number of subscribers of the internet-channel or the number of "likes" of the "twitter" are the most common criteria for what is right and good. For example, it is very interesting to see how quickly the traditional marketing basis is destroyed by the reposting just one "twitter" of the uneducated but very popularity "marketing" company in which the free-in-reasoning hipsters work. In most cases these hipsters have no any classic education. Although they have some "education" yet, but this "education" is also estimated by numbers by number of courses and trainings which were conducted by such "hipsters"... So, the society is in the closed circle of the degradation and the destruction of classical education, which must be the basis of the culture.

According to this approach, the courses of a young coach, who has gone through, for example, six jobs for three years, is more "luxury" (due to his "work experience") than the other one that has got classical education at the university. But it is necessary to clarify exactly who uses such criteria for the education quality evaluation. Do the employers use such criteria? Yes, they do. Especially it may be if these employers aren't going to pay much money to employees. Actually it will be very beneficial for the employers to recruit the half-taught students for low-skilled work.

There is the main threat for the humankind: under the conditions of the information chaos any person can become the author (or the authors) of the global culture of the future as the new instrument for the global management of the human activity. Anyone is able to use opportunities of the information and communication technologies (ICT) for the global spread of information. Is there the guarantee that the modern authors of 
the global culture of the future will not "re-create the wheel" that has been already created in the form of the religions? According to the definition, the "religion" is "the one of forms of the social consciousness, the complex of mystical ideas that are based on the belief in the supernatural forces and the creatures (gods and spirits), which are the subject of the worship" (Ozhogov, 1988, p. 552). Or will they take it upon theirselves to innovatively interpret the meaning of the humankind values and adopt them to the modern conditions? But how will they exactly do this? What are their own cultural traditions and education? Which are their values, what is their moral? And what will their goals be?

Under the conditions of mass degradation of the global society the person becomes very vulnerable to the point impacts of the interpretations the meaning of some events. So, if the author of the global culture of the future uses the communication instruments which can oversimplify the understanding of the cultural postulates he will have a lot of mass followers. Under the conditions of the chaos the efficiency increases especially too much (Cialdini, 2006, pp. 113-156). According to this principle, the behavior of the most people is the main criteria of the correct behavior for other people in some situations. For people who don't have own clear benchmarks and who are very vulnerable to the external impact it lead to the many duplications and the clones of the specific behavior of the people. But we must understand that the behavior (which is proposed by the author of the global culture of the future) may not be correct initially...

Under these conditions there is a very high probability of the emergence of new ideas, new religions (which even are based on the existing traditional religions). For example, the group of the Dutch researchers conducted the experiment of the attitude the people to the sacred scripture $(\mathrm{R}, 2015)$. They read aloud to the passers (respondents) the citations from the Bible, which are most contradicted to the Western outlook to the modern life. But before the experiment they had wrapped the Bible into the cover on which the title "Koran" had been written. The majority of respondents who had thought that these citations were from the "Koran" expressed the negative opinion about these citations. But then the researchers demonstrated them the real cover of the Bible and it really surprised all the respondents. 
The technologies are very available today and any book can be printed in any printing house or be published by the internet. So, it may become the long advertising message. And the film or the video-lecture may become the long advertising video. Although in the initial phase of that communications the target audience doesn't even aware that it watches or reads just the commercial product, not the product of the art. But the commercial product always has the commercial targets.

\section{Conclusions}

For the future shock prevention we have to prepare for the future by learning various forecasts of the future (Toffler, 2002). Once Roberto Oros di Bartini, the famous aircraft designer of the War II, was asked how the economy could outrun another outstripping economy. He answered: "It is impossible. But we can move from the opposite direction to it for meeting".

The future is inevitable. But it is impossible to be ready for everything because it is impossible to outrun the future. So, we have to move from the opposite direction to it. It means that the humankind has to have the measure (standard) of the future, the clear criteria of what is right and what is wrong, which we will be able to impose on the chaos. We wouldn't lose the main reference points of the humankind values that were tested by the time. From our point of view this is the best preparation of the humankind to the future and the best instrument for the management of the future.

When we learn something we have to learn its history (the history of the country or the history of the marketing). Considering a sharp increase of the Big Data the history has to be learned in the reverse chronological order (from the modern contemporary history to the old ancient history), from the particular to the general (from the history of the native country to the history of all countries over the world). But first of all the educational programs should be designed by the highly moral teachers which have good classical education, strong reference points of the humankind values and are able to implement the innovations in the educational process. Sure, some innovations can destroy the previous traditional approach. But, if 
these innovations are good substantiated, they will be accepted by teachers and widespread among the people. The global culture of the future must be formed with just such way.

\section{References}

1. Bannikova, Y. B. (2012). Organizacionnaja kul'tura kak instrument upravlenija personalom organizacii (Organizational culture as the instrument of management of the personal). Vcheni zapiski KhGU - Proceedings $K h G U$, »NAU«, 18, 56-64.

2. Bartol Jr., T. M., Bromer, C., Kinney, J., Chirillo, M. A., Bourne, J. N., Harris, K. M., \& Sejnowski, T. J. (2015). Nanoconnectomic upper bound on the variability of synaptic plasticity. Retrieved from http://elifesciences.org/content/4/e10778\#sthash.uhQ9nW9u.dpuf

3. Bazarov, T. Y. \& Yeremin, B. L. (2002). Upravlenie personalom: uchebnik dlja vuzov (Workforce management). Moscow: Banki i birzhi, JuNITI.

4. Cialdini, R. B. (2006). Psikhologiia vliianiia = Influence science and practice. St. Petersburg: Piter.

5. Dorofeev, V. D. \& Beliakova, V. A. (2012). K voprosu o dolgosrochnom marketingovom prognozirovanii rynka (According to long-term marketing forecasting). Izvestija VUZov. Povolzhskij region. Obshhestvennye nauki - News of Higher Educational Institutions, Povolzhskiy Region, Social sciences, (1), 209-216. Retrieved from http://cyberleninka.ru/ article/n/k-voprosu-o-dolgosrochnom-marketingovom-prognozirovanii-rynka

6. Dudina, M. N. (2011). Neobhodimost' noosfernogo obrazovanija v globalizirujushhemsja mire (Necessity of noospheric education in globalising world). Cheljabinskij gumanitarij: nauchnyj zhurnal - Chelyabinsk scholar: academic journal, 2(15).

7. Efimchuk, I. V. (2005). Globalistika i futurologija. Social'naja organizacija - proshloe bez budushhego? Naivnye voprosy diletanta (Globalistics and futurology. Social organization - is it the past without the future?). Obshhestvennye nauki i sovremennost' - Social sciences and modern era, (3), 144-153. Retrieved from http://ecsocman.hse.ru/data/2010/12/15/1214861820/Efimchuk.pdf

8. Fomichov, S., Banin, A., Skachkov, I., Lysak, V., Gaievskiy, O., \& Yudina N. (2019). Standard Management Systems. Quality Management. Kyiv: KIM.

9. Gelovani, V. A., Britkov, V. B., \& Dubovskiy, S. V. (2010). Globalistika i futurologija. Informacionnoe klonirovanie $\mathrm{v}$ processah globalizacii (Globalistics and futurology. Information cloning in globalization processes). Ekonomika. Sociologija. Menedzhment: Federal'nyj obrazovatel'nyj portal. Retrieved from http:/ecsocman. hse.ru/data/2010/12/16/1214863198/Gelovani.pdf

10. Gustavson, D. E. et al. (2015). Understanding the cognitive and genetic underpinnings of procrastination: Evidence for shared genetic influences with goal management and executive function abilities. Journal of Experimental Psychology: General, 144(6). 
11. Hardy, B. (2016). 10 Reasons Why C Students Are More Successful After Graduation. Retrieved from http://observer.com/2016/02/10-reasons-why-c-students-are-moresuccessful-after-graduation

12. Hel, I. (2015). Iz chego moglo by sostoiat prostranstvo-vremia? (From what form of part of space-time may be?). Novosti vysokikh tekhnologii - Hi-News.ru. Retrieved from http://hi-news.ru/research-development/iz-chego-moglo-by-sostoyat-prostranstvovremya.html

13. Imaeva, N. R. (2010). Ideologija: ot politicheskih doktrin k upravleniju korporaciej (Ideology: from political doctrine to corporative governance). Izvestija vysshih uchebnyh zavedenij. Povolzhskij region. Gumanitarnye nauki, 2(14), 28-33. Retrieved from http://cyberleninka.ru/article/n/ideologiya-ot-politicheskih-doktrin-k-upravleniyukorporatsiey

14. Ivenko, L. I. (1992). Uroki amerikanskogo menedgmenta (The lessons of American's management). In Mascon, M. H., Albert, M., Headwoury, F., Osnovy menedgmenta (The bases of management) (pp. 5-17). Moscow: Delo.

15. Kibanov, A. Y. (2002). Upravlenie personalom organizacii. Praktikum: ucheb. posobie (Workforce management of the organization. Practicum: education guidance). Moscow: INFRA-M.

16. Kniazeva, E. N. \& Kurdumova, S. P. (2002). Osnovanija sinergetiki. Rezhimy s obostreniem, samoorganizacija, tempomiry (Bases of synergetics. Blow-up regimes, selforganization, tempoworlds) (pp. 38-39). St. Petersburg: Piter.

17. Kuzmich, Y. V. (2016). Pokemon GO: myli stvorinnia chy zalezhnist'? Scho oberesh ty? (Pokemon GO: nice creations or dependences). Innovatsii ta fundamental'ni nauky v umovakh tekhnohennoi ekonomiky: zb. materialiv mizhdystsyplinar. nauk.-prakt. konf. Kyiv. Retrived from: http:/futurolog.com.ua/publish/2/Zbirnyk .pdf\# page $=70$

18. Nechitailo, S. D. \& Yudina, N. V. (2015). Instagram kak jeffektivnyj instrument marketingovyh kommunikacij na mezhdunarodnyh rynkah (Instagram is effective instrument of marketing communications at the International markets). Mizhnarodna ekonomika: integracija nauk ta praktiki: Zbirnik nauk. prac' NTUU »KP? «. Kyyiv: NTUU "KPI", 58-64. Retrieved from http://ied.kpi.ua/wp-content/uploads/2015/09/IE2015.pdf

19. Ozhogov, S. I. (1988). Slovar' russkogo jazyka: Ok. 57000 slov (Dictionary of the Russian Language: about 57000 words). Moscow: Rus.yaz.

20. Parkinson, C. N. (1989). Zakony Parkinsona (Paekinson's laws): sbornik: per. s angl., Sost. i avt. predisl. V. S. Murav'ev. Moscow: Progress.

21. Petty, R. E., Rucker, D., Bizer, G., \& Cacioppo, J. T. (2004). The elaboration likelihood model of persuasion. In J. S. Seiter \& G. H. Gass (Eds), Perspectives on persuasion, social influence and compliance gaining (pp. 65-89). Allyn \& Bacon.

22. R (2015). Relihijnyj eksperyment: perekhozhym prochytaly tsytaty $z$ Biblii, vydavshy ii za Koran. Retrieved from http://socportal.info/2015/12/12/religijnij-eksperimentperehozhim-prochitali-tsitati-z-bibliyi-vidavshi-yiyi-za-koran.html 
23. Reva, O. V. \& Yudina, N. V. (2013). Osoblyvosti Marketynhovykh Doslidzhen' Instrumentamy Sotsial'nykh Merezh V Ukraini. Mizhnarodna ekonomika: integracija nauk ta praktiki: Zbirnik nauk. prac' NTUU»KP? «. Kyyiv: NTUU »KP? «, 160-165.

24. Schedrovitskiy, G. P. (1995). Dva poniatyia systemy. Yzbrannye trudy (Two concepts of a system. Selectas). Moscow: Shk. kul'tur. polytyky.

25. Schein, E. H. (1985). Organizational culture and leadership: A dynamic view. JosseyBass.

26. Smovzh, I. (2013). Marketolohy dolzhny prevratyt'sia $v$ futurolohov y pohriaznut' $v$ melochakh (Marketers have to turn into futurology specialists and get immersed in trivia). Retrieved from http://adindex.ru/publication/opinion/marketing/ 2013/05/27/99250.phtml

27. Syuniakova, I. R. (2016). Pokemon GO ta RL-ihry $v$ informatsijnomu suspil'stvi (Pokemon GO and RL-games in informative society). Innovatsii ta fundamental'ni nauky $\mathrm{v}$ umovakh tekhnohennoi ekonomiky: zb. materialiv mizhdystsyplinar. nauk.prakt. konf. Kyiv. Retrived from http://futurolog.com.ua/publish /2/Zbirnyk.pdf\# page $=67$

28. Toffler E. (2002). The Future Shock. Moscow: AST.

29. Veber, A. B. (2013). Model' ustojchivogo razvitija i aktual'nost' Marksa. Al'ternativy Alternatives, (2), 19-30. Retrieved from http://www.isras.ru/publ_mainlist.html?fid $=\% \mathrm{C} 2 \% \mathrm{E} 5 \% \mathrm{E} 1 \% \mathrm{E} 5 \% \mathrm{~F} 0 \% 20 \% \mathrm{C} 0 . \% \mathrm{C} 1$

30. Vetoshkina, T. (2009). Organizacionnaja kul'tura kak instrument upravlenija personalom v uslovijah peremen (Organizational culture as instrument of management of workforce under the conditions of changes). Kadrovik - HR manager, 11(3), 14-20. Retrieved from http://elibrary.ru/item.asp?id=19046401

31. Vihanskiy, O. S. \& Naumov, A. I. (2000). Menedzhment (Management). Moscow: Gardika.

32. Vilhovichenko, E. D. (1994). Novoe v kul'ture truda, proizvodstva, kompanii (The new in culture of labor, production, company). Mirovaja jekonomika $i$ mezhdunarodnye otnoshenija, (12).

33. Yudina, N. (2017). Wskrzeszenie przez Ukrzyżowanie. Michat Szpak. Nonfiction. Warszawa, Olsztyn: OLDRUK. Retrieved from http://futurolog.com.ua/publish/ michalszpak_pl.phtml

34. Yudina, N. V. (2014). Predposylki futurologii v sisteme obrazovanija marketologov (Preconditions of futurology in the system of education in marketing), Social'naja jekonomika, (1-2), 187-193. Retrieved from http://nbuv.gov.ua/UJRN/ se_2014_1-2_32

35. Yudina, N. V. (2020). Atypovist' i asynkhronist' hlobal'nykh ekonomichnykh kryz. Sustainable Development under Conditions of Uncertainty and Catastrophes: Collection of Materials of the International Multidisciplinary Scientific and Practical Conference, iyiv, pp. 60-63. Retrieved from http://futurolog.com.ua/publish/ 17/zbirnyk.pdf\#page $=60$ 
Nataliya Yudina, PhD, National Technical University of Ukraine "Igor Sikorsky Kyiv Polytechnic Institute", Industrial Marketing Department, Ukraine - the Laureate of the President of Ukraine Prize for young scientists, scientific degree of $\mathrm{PhD}$ in Economics, an academic rank of Associate professor with the four higher education degrees, a two-time winner of the "Young lecturer and researcher of the NTUU KPI" contest, a grant-holder of the Kyiv City State Administration Head, a winner of the All-Ukrainian Young Teachers Contest by Philip Kotler, Associate professor of the Industrial Marketing Department of the Management and Marketing Faculty at National Technical University of Ukraine "Igor Sikorsky Kyiv Polytechnic Institute", a founder of the group of the companies Factory of Decisions "Scarlet Sails", the author and the developer of distance e-learning courses of the Nonfiction-publisher "Futurolog" (http://futurolog.com.ua), an author of more than 250 publications. More details read http://futurolog.com.ua/yudina/ 